преобразователя без RC-цепочки. Эти зависимости показывают, что преобразователь самостоятельно запуститься не может. На рис 4, б показаны те же зависимости, но параллельно нагрузке включена RC-цепочка: $R=2000$ Ом, $C=5$ мкФ. Преобразователь уверенно запускается.

\section{СПИСОК ЛИТЕРАТУРЫ}

1. Тиховод, С. М. Программа для компьютерного моделирования электрических процессов в тирис- торных цепях / С. М. Тиховод, Т. М. Корнус // Електротехніка та електроенергетика. - 2002. - № 1 .

2. Ортега, Дж. Введение в численные методы решения дифференциальных уравнений / Дж. Ортега, У. Пулл. - М. : Наука, 1986. - 288 с.

3. Тиховод, C. М. Разработка компьютерной программы моделирования магнитоэлектрических цепей, содержащих тиристоры / С. М. Тиховод, И. О. Афанасьева, Т. М. Корнус // Технічна електродинаміка. - 2009. - № 3. - С. 9-13.

Стаття надійшла до редакиї 03.06.2011.

Корнус Т. М., Тиховод С. М.

Моделювання пуску тиристорного перетворювача для живлення обмотки збудження турбогенератора

Розроблено MATLAB -програму для моделювання електричних процесів в тиристорних перетворювачах, щуо описуються жорсткими диференціальними рівняннями. За допомогою проведених досліджень розроблено рекомендації пуску перетворювача з|із| великим індуктивним навантаженням.

Ключові слова: моделювання, тиристорний перетворювач.

Kornus T. M., Tykhovod S. M.

Modeling of thyristor converter start for turbogenerator excitation winding power supply

The MATLAB program is developed, modeling electric processes in thyristor converters which are described by rigid differential equations. Based on investigation results recommendations are given for converter start under high inductive load.

Keywords: Modeling, Thyristor Converter

УДК 621.316.925:621.3.049.77

V. I. Gurevich

Central Electric Laboratory, Israel

\title{
RELIABILITY OF MICROPROCESSOR-BASED PROTECTIVE DEVICES - REVISITED
}

\begin{abstract}
The article is a continuation of a set of the author's previous publications about the reliability of the microprocessorbased protective devices. The statistical data introduced by the author, coincide with data of other authors and confirm higher reliability of electromechanical relays in comparison with microprocessor-based. The inadequacy of the criterion for estimating the reliability of the protective relay is noted and a new normalized criterion for such estimation is offered by author.
\end{abstract}

Keywords: microprocessor-based protective devices, reliability, relay protection, life expectancy, intensity of failures, failure rate.

\section{Introduction}

In previous publications the author has already analyzed the transition from electromechanical to a microprocessor-based protective relays, and considered the prospects and problems of microprocessor relays applications [1-4]. The rather sharp reaction of the readers, often arising after these publication, on the one hand, and the author's detailed answers to the criticism of opponents on the other show that among the specialists in this area there is no common opinion about the prospects of microprocessor protection, there is no unequivocal understanding that, as any other complex device, the microprocessor protection not only possesses obvious advantages, but also has serious weaknesses.

2. Myth about the extremely importance of microprocessor-based protective devices

One of the widely widespread fables [5] justifying the inevitability of transition to microprocessor relay protection is the myth that electromechanical protective relays do 
not provide the performance of the technical requirements for relay protection and the further existence of electric power industry of today is not possible without microprocessor protection devices (MPD).

Actually, no new functions in relaying MPD have been introduced. The parameters and facilities of the high-quality electromechanical and semi-conductor, that is, the static analog devices constructed on the basis of discrete solidstate elements and integrated microcircuits, completely provide all relay protection requirements. In relaying there are no actual problems that could not be solved by means of electromechanical or static relays (note: recording emergency modes is not relay protection function). Confirmation of this is the fact that complex electrical networks and systems exist and successfully function all over the world for more than hundred years; whereas microprocessor-based relay protection has appeared in use in not very appreciable numbers just 10-15 years ago. Thus, with the beginning of the use of MPD the functioning logic of an electric power system has not changed, the number of operations that are carried out by an electric power system has not increased, the quantity of the produced electric power has not changed, principles of transmission and distribution of the electric power have not changed.

\section{Why has a microprocessor-based protective device become so popular?}

The progress in the development of electromechanical relays completely stopped 30-35 years ago since the efforts of developers have been directed first to the creation of electronic profections and then to microprocessor-based ones. The matter is that the production expenses of a completely robotized (down to automatic testing) MPD manufacturing process using cheap high-integrated electronic components is far less than the expenses of manufacture and manual assembly precision mechanical elements of electromechanical relays; therefore it is to the manufacturer's interest to push MPDs. For example, the ordinary electronic component mounting machine, CM402$\mathrm{M} / \mathrm{L}$, can install 60,000 components an hour. Yes, 60 thousand components an hour! It is evidently clear that with such high-efficiency fully automatic manufacture of printed-circuit-boards, of which one is the MPD, brings to manufacturers fabulous profits in comparison to manufacture of mechanical relays. In the manufacturing sphere we see that the most important advantage that MPD has are enormous profits for the manufacturers. Apologists for the widespread use of MPD often bring up such reasons in favour of the MPD as the ability to record emergency modes which is absent in electromechanical relays, the ability interchanging information between the relay units, etc. But all these are advertising gimmicks which have no connection with the reality. Today in the market there are hundreds of versions of microprocessor recorders of the emergency modes capable of transmitting data over networks, which records emergency modes much better and more fully than MPD. There are information transfer systems, such as SCADA, that have worked well for many years with electromechanical relays. Unlike the relay of protection, microprocessor-based recorders are not capable of affecting the reliability to effect supply and initiate collapses in a network at failures.

In many electric power systems electromechanical relays until now reliably protect many crucial power installations of all voltage classes and other utilities equipment. Sometimes electromechanical protective relays include working in parallel with microprocessor-based relays for maintaining greater reliability of the important electric installations and especially crucial equipment, Fig. 1.

Thus it often appears (especially in cases of complex damages with transition of one kind of short circuit to another) that electromechanical protection works noticeably more quickly than microprocessor-based ones.

In many electric power systems the normalized terms of electromechanical relays work are coming to the end of their lifespan, many of them are in rather sad state and the operational personnel see that transition to MPD is the only alternative for maintaining the working capability of relaying because of the is manufacturers dictatorship (see above). Today in the world market there are simply no electromechanical protection relays being developed using modern materials and technologies, and all leading world protection relay manufacturers have gone over to exclusively manufacturing MPDs. At the same time, progress in the field of new materials, components and

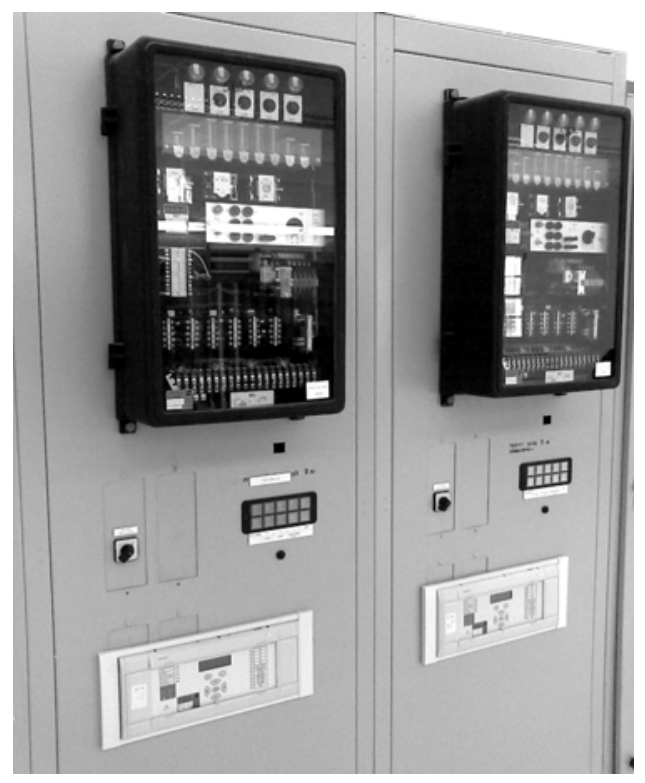

Fig. 1. Fragment of the protection panel at a distance of crucial lines $161 \mathrm{kV}$ containing electromechanical relays of LZ31 type (above) included for working in parallel with an MPD type MiCOM P437 (below) 
technologies allow constructing the protective relays on completely new principles in which it is possible to construct, for example, hybrid relays [6]. Unfortunately, today's MPD manufacturers, faced with the increasing functional complication of their products with no significant means to decrease MPD manufacturing costs, are not interested in investing in any alternative kinds of the relays to compete with the profitability if the MPD. And, profitability of the MPD stems not only from the wide difference between the production price and sale price, but also from use of the new production technology (surface mounting of super miniaturized elements and high integrated microcircuits on the multilayered printed-circuitboard) that presupposes no repairing of MPD modules. It is now common to throw out the failed MPD modules made using this technology and replacing it by a new one. Such approach is advertised by MPD manufacturers as high maintainability of their products. But considering that the whole MPD costs 10-15 thousand US dollars consisting of 4-5 of such modules (separate printed-circuit-boards), it becomes clear what the meing such «maintainability» is to the consumer (that is to electric power systems).

The ageing and service life of would be too expensive protection devices are directly connected with MPD reliability and their costs. For MPD (as well as for electromechanical relays) in many countries the normal life expectation is 20-25 years [8]. Actually, many electromechanical relays are in service about 30 and even 40 years while the computer based devices age much more quickly.

Keep in mind the physical ageing of electronic components, such as electrolytic capacitors (the service life of which does not exceed 7-10 years) and others, and especially the software. So, according to [10] the life expectancy of designed obsolescence (Fig. 2) has sharply decreased from 30 years, for the traditional electromechanical relays to, approximately, 5 years for modern MPD. This means, that MPD users have to spend much greater sums in future for updating of relaying (both hardware and software) and much more often than they had to do earlier when using electromechanical protection.

Despite the problems noted above, the tendencies in relay protection development are such that widespread and increasing use of MPD is made inevitable. The MPD expansion is connected not only with necessity of replacing the old electromechanical relays with finished normative terms, but also with installing in-service new power elements, the last 10-15 years all over the world has seen the gradual transition to relaying of the new generation based on microprocessors. To «push» MPD on the market the manufacturers of these devices, and their numerous sales representatives, are engaged in strong advertising campaigns in eulogizing MPD in every possible way while belittling the advantages of the relay of other types. The basic thesis of these advertising campaigns is the statement that MPD provides very high reliability relaying unlike the

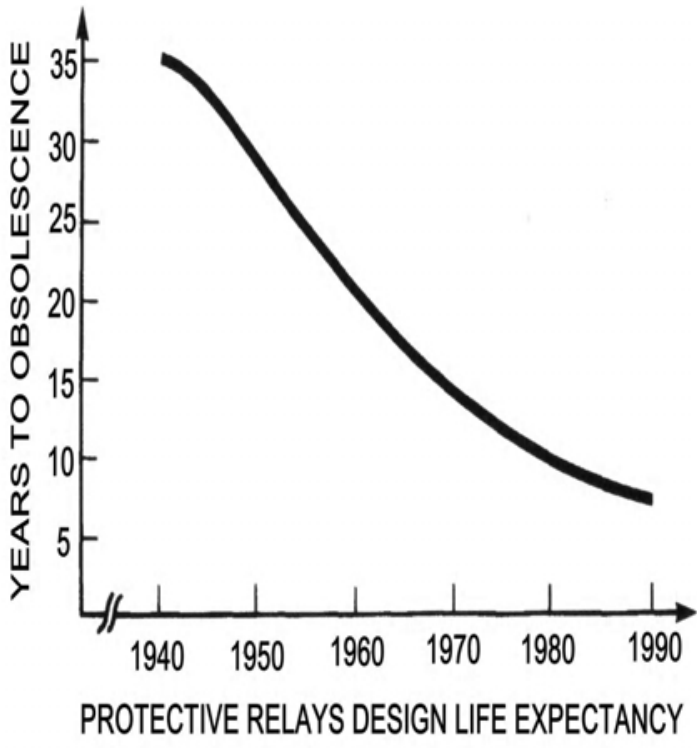

Fig. 2. Protective relays design life expectancy [10]

old and worn out electromechanical relays which are approaching their age limit. At the same time, it is abviously clear that MPD is a complex technical system consisting of many thousand of components. Like any other complex electronic systems, they should have failures and cannot possess absolute reliability, especially if one is to consider the «hothouse» operating conditions in power electrical networks. This being so, one would expect there should be many publications in technical literature considering the technical problems of microprocessor relays. How many such articles considering to MPD problems have you read? It is a significant fact that the overwhelming majority of publications in the technical journals devoted MPD is written by engineers of the MPD manufacturing companies. Naturally enough these publications represent the direct or veiled advertising, and not serious analysis of problems with reliability or other quite real MPD problems which exist in MPD. Since the MPD manufacturers are the advertisers generously paying for significant areas of journal pages, the journals are extremely reluctant to accept articles devoted to the criticism of MPD, and sometimes do not hesitate in declaring this. One gets the feeling that there is a certain taboo imposed on discussion on this theme. If an author happens to break by chance through this «Iron Curtain» [1-4], there is a squall of criticism including personal attacks and even charges of attempts to brake the technical progress.

\section{The actual problem with reliability of microprocessor-based protective device}

In [4] we have already considered, in detail, problems with the reliability of each of the basic functional units of MPD and have shown, through concrete examples, that the so-called «self-diagnosis» by which $80 \%$ of MPD units are ostensibly captured, is, by and large, an advertising 
gimmick and a widespread myth. While it is true that selfdiagnosis in MPD can reveal some internal damages, for example, such as failure of the internal power supply or the central processor unit (CPU), how it is possible to speak seriously about this as about a great «advantage» of MPD against of electromechanical relays if in the electromechanical relays there are no internal power supplies and CPUs, that is, there is simply nothing to «self-diagnose»?!

As brought out in [4] the analog input modules (current and voltage transformers), digital inputs, output relays are not captured by a self-diagnosis in MPD. In addition, as shown in [4], the system of a self-diagnosis is constructed on microprocessors and memory elements, so it is an additional source for malfunctions of MPD. Actually the self-diagnostics is not an advantage of MPD against electromechanical relays, and is only a partial compensation for very serious MPD disadvantages: concentration of many protective functions in the single module. For example, only single MPD type M-3430, Fig. 3, provides a full protection of the generator on power station from all possible emergency modes and combined functions of 14 separate protective relays. It is only possible to speculate what would occur if this MPD malfunctions at emergency mode due to fault of any cheap internal component in the power supply or CPU. The high power and very-very expensive generator WOULD STAY WITHOUT ANY PROTECTION!

It is absolutely clear that without self-diagnostics it would be impossible to admit such combined protection device on a gun shot to protection of electrical power installations. So, the self-diagnostics in MPD is a forced measure, and not so beautiful application; therefore to advertise it as a great achievement in relaying is absolutely not justified.

Strangely enough, but opponents of the author's position do not deny the our position on the problems of the MPD units, rather they concentrated only on criticism of some general opinions and reasons about MPD reliability, borrowed by the author (with corresponding numerous references) from others who investigated the problem. We decided to carry out our own research by using statistical data on protective relay malfunctions for 2007-2008 of one of the electrical power companies (for ethical reasons we do not publish the name of this company).

Initial statistical data on relay protection failures and calculations are given in Tables 1 and 2 .

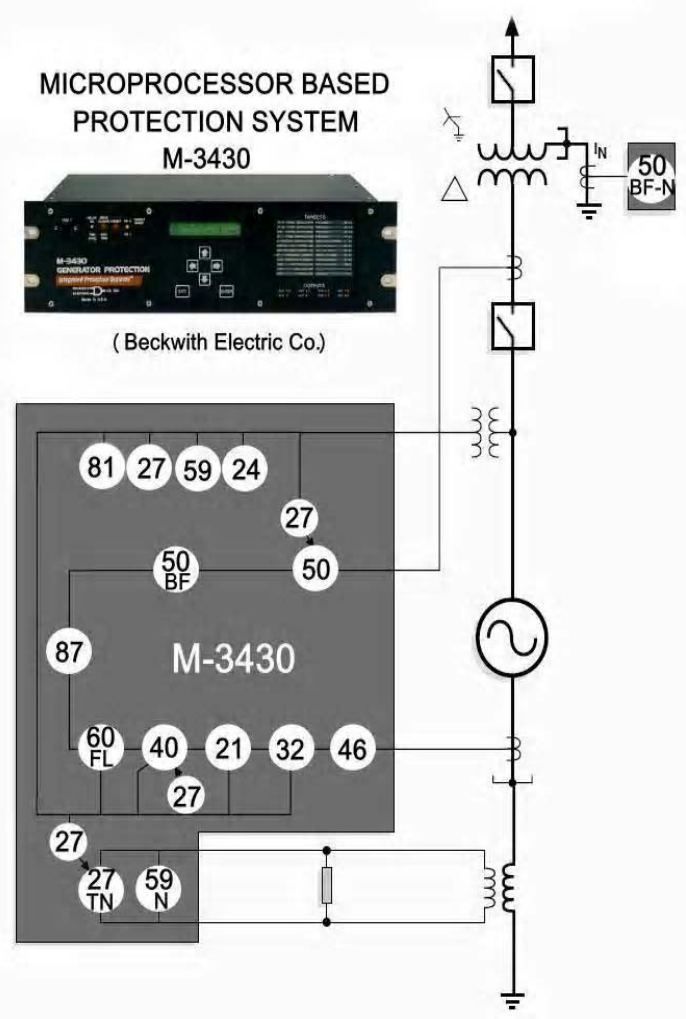

Fig. 3. Structure of the microprocessor-based system M-3430 type (Beckwith Electric Co.) for complete protection of power generator

Table 1 - Failure rate of protective relays of various kinds

\begin{tabular}{|c|c|c|c|c|c|c|}
\hline \multirow{3}{*}{$\begin{array}{c}\text { Parameter } \\
\text { Relay kind } \\
\begin{array}{c}\text { Total number of relays in } \\
\text { service }\end{array}\end{array}$} & \multicolumn{2}{|c|}{ Electromechanical } & \multicolumn{2}{|c|}{ Static } & \multicolumn{2}{|c|}{ Microprocessor-Based } \\
\hline & 2007 & 2008 & 2007 & 2008 & 2007 & 2008 \\
\hline & \multicolumn{2}{|c|}{2312} & \multicolumn{2}{|c|}{2745} & \multicolumn{2}{|c|}{3787} \\
\hline Number of failures & 1 & 4 & 8 & 8 & 43 & 51 \\
\hline Relative failures ${ }^{1}, \%$ & 0,043 & 0,173 & 0,291 & 0,291 & 1,135 & 1,347 \\
\hline $\begin{array}{c}\text { Average relative yearly } \\
\text { failures }{ }^{2}, \%\end{array}$ & \multicolumn{2}{|c|}{0.11} & \multicolumn{2}{|c|}{0.29} & \multicolumn{2}{|c|}{1.24} \\
\hline $\begin{array}{c}\text { Yearly intensity of } \\
\text { failures }^{3}\end{array}$ & \multicolumn{2}{|c|}{1} & \multicolumn{2}{|c|}{2.6} & \multicolumn{2}{|c|}{11.3} \\
\hline
\end{tabular}

${ }^{1}$ Relative failures is relation of failure numbers for some relay kinds to total number of relays of same kind

${ }^{2}$ Average relative yearly failures is average number of relative failures for two years (2007 and 2008)

${ }^{3}$ Yearly intensity of failures is ratio of average numbers of relative yearly failures of different kinds of relays to the same parameter of electromechanical relays (defined as 1). 
Table 2 - Growth of relay protection failures at usage of new kinds of relays

\begin{tabular}{|c|c|c|c|c|c|c|c|c|}
\hline \multirow{3}{*}{$\begin{array}{l}\text { Start } \\
\text { service } \\
\text { year }\end{array}$} & \multirow{3}{*}{ Relay kinds } & \multirow{3}{*}{$\begin{array}{c}\text { Total } \\
\text { number } \\
\text { of relays }\end{array}$} & \multicolumn{6}{|c|}{ Failures } \\
\hline & & & \multicolumn{2}{|c|}{ Total number } & \multicolumn{2}{|c|}{ Relative, $\%$} & \multirow{2}{*}{$\begin{array}{c}\text { Average } \\
\text { relative } \\
\text { yearly, \% }\end{array}$} & \multirow{2}{*}{$\begin{array}{c}\text { Failures } \\
\text { yearly } \\
\text { intensity }\end{array}$} \\
\hline & & & 2007 & 2008 & 2007 & 2008 & & \\
\hline $\begin{array}{l}1970 \\
1975\end{array}$ & Electromechanical & 2312 & 1 & 4 & 0,043 & 0,173 & 0.11 & 1 \\
\hline $\begin{array}{l}1975 \\
1980\end{array}$ & Electronic (Static) & 2745 & 8 & 8 & 0,291 & 0,291 & 0.291 & 2.6 \\
\hline $\begin{array}{l}1990 \\
1995 \\
\end{array}$ & $\begin{array}{c}\text { Microprocessor-based } \\
\text { Type } 1 \\
\end{array}$ & 1423 & 19 & 25 & 1,33 & 1,76 & 1.54 & 14 \\
\hline $\begin{array}{l}2000 \\
2005\end{array}$ & $\begin{array}{c}\text { Microprocessor-based } \\
\text { Type } 2\end{array}$ & 342 & 6 & 5 & 1,75 & 1,46 & 1.61 & 14.6 \\
\hline $\begin{array}{l}2003 \\
2005\end{array}$ & $\begin{array}{c}\text { Microprocessor-based } \\
\text { Type } 3 \\
\end{array}$ & 49 & 3 & 1 & 6,12 & 2,04 & 4.08 & 37 \\
\hline $\begin{array}{l}2005 \\
2008\end{array}$ & $\begin{array}{c}\text { Microprocessor-based } \\
\text { Type } 4\end{array}$ & 10 & 3 & 1 & 30 & 10 & 20 & 182 \\
\hline
\end{tabular}

It is possible to come to two important conclusions (which can seem paradoxical to someone) resulting from our calculations:

1. Yearly intensity of failures for microprocessor-based protective relays is much more than electromechanical.

2. Yearly intensity of failures of protective relays significant by increased over the past few years in connection with usage of new kinds of protective relays. That is, for the past few years the tendency for decrease in $M P D$ reliability, Fig. 4, is taken place.

Actually, there is nothing unusual in these conclusions. According to other statistic data, presented in [11], it is quite visible that electronic (static) relays have three times greater damageability than electromechanical, and microprocessor-based relays have 50 times greater damageability, Table 3.

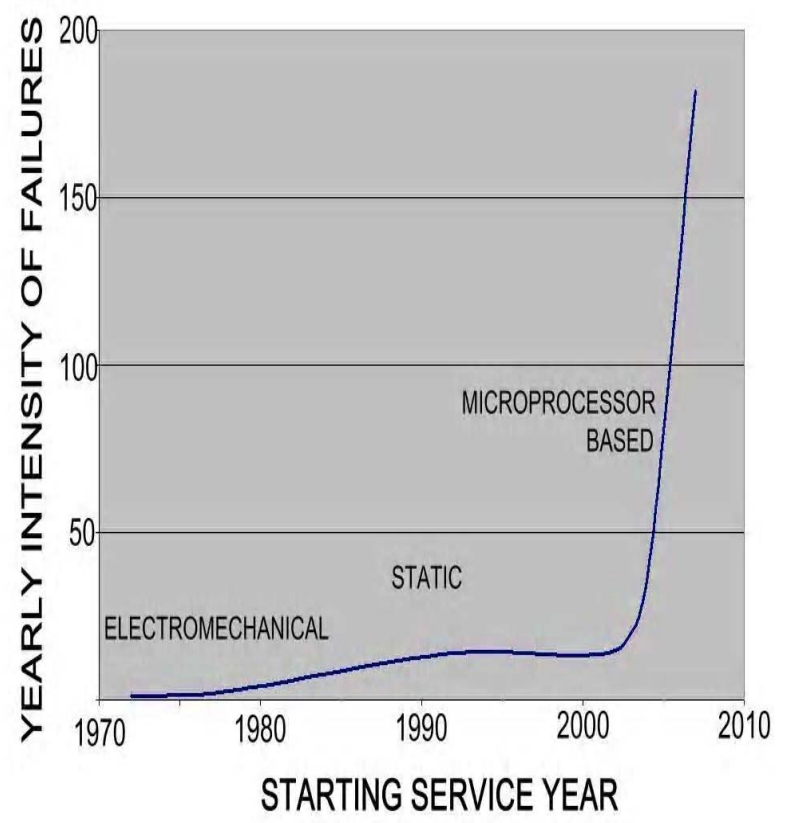

Fig. 4. The tendency of increasing failures for MPDs of new types (according to Table 2)
However, as was noted, insofar as one microprocessor protection incorporates the functions of several relays, this should be taken into account when making a comparative estimation of reliability. For example, if one MPD carries out protective functions of 10 single electromechanical relays, the difference between them in damageability will be only 5 times, not 50 . At first sight, such an approach is quite logical; however, it does not consider the fact that MPD contains such common units as power supplies, CPUs, input analogue electronic circuits, etc., faults of which lead to failure of all these 10 virtual relays at once. That is to say, that weight factor of a single fault in a multifunction MPD is more (in our instance: 10 times) than in the single-functional electromechanical relay. For this reason it is possible for us, in order not to complicate the business, to continue the comparison of to compare the failure rate of microprocessor-based and electromechanical relays without taking into account the difference in number of functions carried out by them.

Important factors, such as mistakes of the personnel (that is, so-called «the human factor»), were not considered in programming the MPD and in working with it. Modern multifunction MPD contain hundreds parameters and set points, tens of inputs and outputs, and can generate thousands of various messages. According to [10] «traditional methods of assessing relays by hardware

Table 3 - Typical failure rates of protective relays (according to [11])

\begin{tabular}{|c|c|c|}
\hline Relay kind & $\begin{array}{c}\text { Failure rate per } \\
\text { year } \\
\%\end{array}$ & $\begin{array}{c}\text { Life without } \\
\text { obsolescence }\end{array}$ \\
\hline Characteristic & 0,1 & $>30$ \\
\hline $\begin{array}{c}\text { Electromechanical } \\
\text { single function }\end{array}$ & 0,3 & $>20$ \\
\hline $\begin{array}{c}\text { Microprocessor } \\
\text { based }\end{array}$ & 5,0 & $>20$ \\
\hline
\end{tabular}


inspection and testing are no longer adequate, since up to $80 \%$ of the engineering design content of contemporary digital relays in the software area». It has therefore become increasingly important for the new generation of relay engineers to have basic knowledge in computers, software, and programming. Absence of such knowledge leads to repeatedly increase of the number of the mistakes related to the «human factor». According to [7] in 2000 the share of guilt of the operational personnel in wrong actions of relay protection in Russia is $61,6 \%$. Also the explanation of the reasons for this is clear: «Insufficient qualification of the personnel of the power enterprises for service of the equipment on new element base».

An additional aggravation of the condition is the presence in single power system of many types MPDs of different manufacturers with very essential differences from each other of the program interface, programming principles, and testing. All this leads to further complication of the process of transition from electromechanical to microprocessor-based protection. In [12] this is directly underscored: «the situation becomes complicated also that the purpose of such transition-substantial increase of efficiency of relay functioning - as a rule, is not attained» and further: «The percent of wrong acts of modern relay panels and cabinets often appears much more than for the old electromechanical relays». This is confirmed in [13]: «the statistics shows, that use of digital protective relays (DPR), despite of its essentially best technical characteristics in comparison with previous generations of protective devices, has not increased, and in many cases even has decreases in number of correct acts of relaying of power equipment».

\section{Criterion for estimation reliability} (failures) of microprocessor-based protective device

In attempting to carry out a similar analysis on failures of relaying in Russia, we have run into an unforeseen problem: it appears that in Russia a base parameter of a reliability assessment in relaying is the percent of correct (or not correct, i.e., faulty) operations [12], instead of the number of relay damages, as in the case considered above.

So, for example, in [14] it is noted that in the most advanced Russian power company «Mosenergo» (Moscow) at the end of 2001 there were already 2332 MPD units of 4 different firms in service and during 4 years only 8 cases faulty operation of MPD have been registered. On this basis authors conclude that «it specifies their high reliability and high service characteristics». In [7] it is also marked that the percent of their correct operations is accepted as the basic reliability index for MPD.

But why is the reliability of the devices and systems estimated by the frequency of their faulty operations instead of the number of damages of their basic internal elements thereby making impossible proper functioning of the device or system? If the signal about damage of its internal power supply (meaning the incapability of the MPD to perform its functions) from MPD installed in protection system was received, but there was no emergency mode in a power network controllable by this MPD (that is, there were no faulty actions of the relaying), this event should not be fixed as failure of MPD and not be considered in the analysis of MPD reliability. Only if the internal damage of the MPD coincides with the time of the emergency mode in a protected network this damage would be considered in a reliability assessment; and if does not coincide, it would not be.

A well known definition for Reliability and Failure [15] is:

Reliability: the ability of an item to perform a required function under stated conditions for a stated period of time.

Failure: refers to the state or condition of not meeting a desirable or intended objective, and may be viewed as the opposite of success.

Failure Rate: the number of failures experienced or expected for a device divided by the total equipment operating time.

However, accident in a power system is the RESULT of relay protection failure, yet the Reliability and Failure definition doesn't even take into account the RESULT stemming from low reliability or high failure rate. It is just not clear why the failure of a single protective unit is taken into consideration only in the case that it is the RESULT of the accident in the power system without any consideration of the accident itself.

It is difficult to see the logic in such approach. Such an approach simply does not lead to the proper analysis of the protective relays failures, similar to the analysis that we have used above.

In our opinion, in the estimation of the relay of protection it is necessary to consider three types of events:

1. The damages (D) of the relay which were not connected with faulty actions of the relaying, but require repair or replacement of the failed elements, unit and modules.

2. Faulty actions (FA) of a relay that is improper operations in the absence of emergency mode or inability to operate (or faulty operation also) in the emergency mode.

3. Personnel mistakes (PM) connected with operation, testing or programming of the relay. Keeping in mind the personal actions that have an influence on the relay functioning properly, but detected before relay improper action occurs.

All these components should be taken into account, in our opinion, when calculating the generalized normalized criterion of failures $F_{\Sigma}$ of relaying:

$$
F_{\Sigma_{i}}=\left(\frac{F_{D_{i}}+F_{F A_{i}}+F_{P M_{i}}}{N_{i}}\right) \times 100 \% \text {, }
$$

Where $F_{D_{i}}, F_{F A_{i}}, F_{P M_{i}}$ - number of failures of each type for the relay of $i$ kind for the considered period of time; $N_{i}-$ number of the relay $i$ kind, being in operation during the considered period of time. 
The suggested parameter could serve as the tool for an estimation of the quality of the relay protection when analyzing a situation and decision-making.

\section{Summary}

In summary, it is desirable to cite the well known expert in the field of MPD, former leading expert of All-Russian Relay Research, Design \& Technology Institute (VNIIR), who worked for a long time at Siemens, Doctor of Science (DSc), prof. M. Shneerson who in the monograph [16] on p. 491 writes:

"In itself increasing technological level of protective relays not necessarily leads to increase of efficiency in reaction on incipient faults. So, for example, become outof-date electromechanical and partly electronic static protective relays at a correct choice of protective functions and setting will certainly provide more effective protection of a network, than microprocessor based without enough proved choice of the specified parameters》

And further, on p. 508:

"As shows a practice, the percent of the wrong actions at usage of digital protective relays, at an initial stage essentially does not decrease, and in some cases even increases».

And in summary, on p. 522:

"Despite of essentially higher technical perfection of the digital protective relays their real operational efficiency, especially at initial stages, appears below, than at protection devices of the previous generation».

\section{REFERENCES}

1. Gurevich, V. Microprocessor Protection Relays: New Prospects or New Problems? / V. Gurevich // Electr. Engineering and Electromechanics. -2006 . - No 3.P. 18-26.

2. Gurevich, V. I. Microprocessor Protective Relays: Alternative View / Gurevich V. I. // «Energo-Info».2006. - No 4 (30). -P. 40-46.

3. Gurevich, V. I. How to Equip a Relay Protection: Opinions of Russian Experts and a View from Outside / V. I. Gurevich // Electric Power's News. - 2007. No 2. - P. 52-59.

4. Gurevich, V. Reliability of Microprocessor-Based Relay Protection Devices - Myths and Reality / V. Gurevich // Serbian Journal of Electr. Engineering. 2009. - No 1 (vol. 6).

5. Gurevich, V. I. Answer from author of the article: «Reliability of Microprocessor-Based Relay
Protection Devices - Myths and Reality» on ctitical review by O. Zacharov, Published on the Web Portal «All about relay protection» (http://www.rza.org.ua/ article/a-64.html).

6. Gurevich, V. Hybrid Reed-Solid-State Devices are a New Generation of Protective Relays, / V. Gurevich // Serbian Journal of Electr. Engineering. - 2007.- No 1 (vol. 4) - P. 85-94.

7. Konovalova, E. $V$. Main results of relay protection devices maintains in power systems in the Russian Federation / E. V. Konovalova // Relay protection and automatics of power systems : Collection of reports of XV scientific and technical conference. - Moscow, 2002 (Rus.).

8. General technical requirements on microprocessor based protective devices and automatics for power systems - РД 34.35.310-97, Moscow, 1997.

9. The review on article by O. Zaharov «The combined power supplies. Characteristics of output circuits»/ O. Zaharov // Published in the magazine «Electric Power's News». - 2009. - No 2.

10. Heising, C. R. Digital Relay Software Quality / C. R. Heising, R. C. Patterson, E. Y. Weintraub// General Electric, GER-3660.

11. Heising, C. R. Reliability Expectations for Protective Relays. Developments in Power Protection / C. R. Heising, R. C. Patterson // Fourth International Conference in Power Protection, 11-13 Apr., 1989, Edinburgh, UK.

12. Shalin, A. I. About efficiency of new relay protection devices / A.I. Shalin // Power and industry of Russia (the selected publications), vol. 203.

13. Shneerson, E. M. Operational efficiency of relay protection devices: a reality and abilities / E. M. Shneerson // Energoexpert. - 2007. - No 4-5.P. 70-77.

14. Kudryashov V. N. Experience with using a microprocessor based protection in Mosenergo / V. N. Kudryashov, V.V. Balashov, A. G. Korolyov, A. V. Sdobin // Relay protection and automatics of power systems : Collection of reports of XV scientific and technical conference. - Moscow, 2002.

15. Ward, S. Improving Reliability for Power System Protection / Ward, T. Dahlin, W. Higinbotham // 58th Annual Protective Relay Conference, Atlanta, GA, April 28-30, 2004.

16. Shneerson, E. M. Digital relay protection/ E. M. Shneerson. - Energoatomizdat, 2007. -548 p.

Стаття надійшла до редакиї 1.06.2009.

\section{Гуревич В.}

Еще раз о надежности микропроцессорных устройств релейной защиты

Статья является продолжением иикла публикаций автора, посвященных надежности микропроцессорных устройств релейной защиты. Приведенные в статье статистические данные, полученные автором, совпадают с данными других авторов и подтверждают более высокую надежность электромеханических реле по 
сравнению с микропроцессорными. Отмечен недостаток применяемого критерия оценки надежности реле защуиты и предложен обобщенный критерий для такой оценки.

Ключевые слова: микропроцессорные устройства релейной защчиты, надежность, релейная защчита, срок эксплуатации, интенсивность отказов, относительное количество повреждений.

Гуревич В.

Ще раз про надійність мікропроцесорних пристроїв релейного захисту

Стаття є продовженням цииклу публікацій автора, присвячених надійності мікропроцесорних пристроїв релейного захисту. Наведені у статті статистичні дані, отримані автором, збігаються з даними іниих авторів і підтверджують більи високу надійність електромеханічних реле у порівнянні з мікропрочесорними. Відзначено недолік критерію оцінки надійності реле захисту, який зазвичай застосовується, $і$ запропоновано узагальнений критерій для такої оцінки.

Ключові слова: мікропроцесорні пристрої релейного захисту, надійність, релейний захист, термін експлуатації, інтенсивність відмов, відносна кількість пошкоджень.

Э. М. Кулинич, В. В. Зиновкин д-р техн. наук Запорожский национальный технический университет

\title{
МОДЕЛИРОВАНИЕ ОПТИМАЛЬНОГО УПРАВЛЕНИЯ ПРОЦЕССОМ ДОЗИРОВАНИЯ МНОГОКОМПОНЕНТНОГО ТЕХНОЛОГИЧЕСКОГО ПРОЦЕССА ПРИГОТОВЛЕНИЯ ГАЗОБЕТОНА
}

\begin{abstract}
Предложены математическая и компьютерная модели системы автоматизированного управления многокомпонентным дозированием технологического процесса приготовления газобетона совместно с симуляцией режимов работы на базе ПЛК и пакетов (PlcSim, Step-7 и WinCC Flexible) фирмы Siemens. Это позволяет разработать инженерные методы снижения простоев исполнительных механизмов и повысить эффективность технологической линии. Приведено моделирование многокомпонентного процесса дозирования жидких составляющих газобетона.
\end{abstract}

Ключевые слова: компьютерное моделирование, дозирование жидких компонентов, многопараметрическая автоматизированная система управления технологическим процессом, газобетон.

Введение. Технологические линии производства газобетонов, как объекты автоматизированного управления, являются многомерными, с линейными и нелинейными взаимосвязями между параметрами различной физической природы. В отдельные моменты времени это приводит к несогласованности режимов исполнительных механизмов и работе электротехнического и электротехнологического оборудования в режимах холостого хода. Это является причиной снижения эффективности технологической линии и качества выпускаемой продукции, непроизводительных потерь электроэнергии и аварийных ситуаций. Для достижения более эффективного управления многопараметрическим технологическим процессом приготовления газобетонов необходимо учитывать возможные несогласованности между каналами управления в процессе дозирования и сократить технологические простои исполнительных механизмов.
Для повышения эффективности и оптимального управления технологическим процессом необходимо исследовать влияние различных факторов и возможных режимов на динамику процесса дозирования технологической смеси газобетона [1]. Для решения этой задачи целесообразно использовать интегральный критерий оптимальности многопараметрической системы автоматизированного управления [1-5]. Его сущность состоит в том, что управление осуществляется по трем обобщённым параметрам. Каждый такой параметр состоит из совокупности сигналов одноименной физической природы и их соответствующего количества [15]. Такой методологический подход использовался в системе многопараметрического автоматизированного управления многокомпонентного дозирования технологической линии приготовления газобетона [3, 4]. Технологический процесс состоит из ряда операций: приготовления смеси из сухих и жидких компонентов, 